\title{
The Characteristics of Inland Water Transport in Nigeria
}

\author{
Dr Obeta Michael Chukwuma \\ Department Of Geography University Of Nigeria Nsukka
}

\begin{abstract}
Inland water transport in Nigeria has had a long history of neglect by both government and the private sector. Little efforts were made to develop inland water transport facilities prior to the 1980s. This stems largely from policy inconsistency, limited private sector involvement, and conflicts between and among agencies involved in the management of inland water transport in Nigeria. Since the 1990s, however, the Federal Government of Nigeria has, taken a number of initiatives, including capital and infrastructure improvement, channels dredging and maintenance and installation of safety facilities to turn round the sector. This paper reports on the current spatial structure of inland water transport in Nigeria; its socio-cultural constraints and contributions to nation's economy, current navigable waterways and goods transported. The purposes are to create awareness, improve attitudes and isolates strategies which can assist all the operators in the inland water transport sector to improve service delivery. Data were collected through oral interviews, field observations and from relevant records in government agencies. Staff of inland water transport agencies, water transport operators and government official responsible for developing and managing inland water transport in Nigeria were interviewed. Additional secondary data were obtained from relevant government agencies. Findings revealed that inland water transport is more popular in the southern deltaic areas of Nigeria where extensive networks of navigable waterways exist. This mode of transport was found to impact positively on the nations' economy as it reduces haulage cost, expands business opportunities, creates jobs and boasts the revenue earned by all the stakeholders in the inland water transport sector. The major socio-cultural challenges which currently impede inland water transport in the study area were identified and described. The way forward is for the federal government to review its investment strategies in the sector and for water transport operators to priorities safety, quality, speed and flexibility in its operation.

Key Words: contributions, social constraints, inland water transport, spatial structure, stakeholders.
\end{abstract}

\section{Introduction}

Inland waterways are made up of navigable rivers, lakes, coastal creeks, lagoons and canals (Aderemo and Mogaji, 2010). The movement of goods and services along inland waterways is one of the oldest means of transporting goods and services from point to point (Fellinda, 2006) This is largely due to the fact that inland water transport (IWT) offers the most economical, energy efficient and environmental friendly means of transporting all types of cargo from place to place (Ojile, 2006). It also offers safer and cheaper rates in areas where water exist naturally. This facilitates commerce, promotes wealth creation, poverty alleviation, and creates job opportunities for youths within such regions. The ancillary sector of boat building industry also generates employment through active engagement of the youths in welding and fabrication process (Gray, 2004).

In Nigeria, Ezenwaji (2010) noted that inland waterways transverse 20 out of the 36 states within the nation and that areas adjacent to the navigable rivers represents the nations' most important agricultural and mining regions. The direct impact of IWT, for instance, was highlighted for the deltaic areas of southern Nigeria by Abubakar (2002) who noted that IWT is very vital and critical for all facets of development in the region. Gray (2006) also noted that about $48 \%$ of all the rural residents in the region live in remote, isolated and inaccessible communities with no motorable roads and another $29 \%$ live in communities with limited services. For such people IWT is absolutely imperative for survival and for accessing social services-education, health etc.

Recently, Obed, (2013) lamented that there has been a considerable decline in the use of IWT in Nigeria. This was attributed to several physical constraints impending growth and performance in the IWT sector in Nigeria. This creates an urgent need for innovative actions and strategies which can radically improve the sector so that it continues to remain the bedrock of trade, industrial and economic growth. In the same vein, Igbokwe, (2007. 16) had observed earlier that the IWT in Nigeria is "untapped goldmine for investors" This shows that the capacity of IWT sector to impact on the economy can be significantly boasted. Indeed, there is increasing awareness that IWT could become an alternative means of transportation to road particularly in Anambra, Imo, Delta, Rivers, Edo, Lagos, Cros-River Akwa Ibom, Ondo and even Borno states. (Ojile, 2007) Given this scenario; it is important to carry out a comprehensive research in order to determine the operational 
patterns of IWT in Nigeria describe the attitudes of stakeholders towards this mode of transport, isolate strategies which can improve performance and, in addition, stimulate the private sector to invest in the inland water transport sector in Nigeria.

\subsection{Review of studies on Inland Water Transport in Nigeria}

Research and publications on inland water transport in Nigeria probably dates back to the pioneering works of Professor R.K. Udo in the 1970s. Udo (1970) noted that water is one of the natural resources which Nigeria has in abundance and that the country has the opportunity to service most landlocked countries in West Africa such as Burkina Faso, Chad, Mali and Niger. Ilojie (1984) also observed that Nigeria is richly endowed with surface water resources and that over 8000 kilometers of the inland waterways are navigable.

Several other researchers such as Adetola (1971), Etu-Effeotor and Odidi (1983) Badejo (1995) Adams (1998, 1999, 2004), Ologunorisa (1999), Douglas (2001), Anyam (2003), Ojile (2006), and have written on various aspects of IWT in Nigeria such as the origin, advantages, neglect, management, problems and potentials of inland water transportation. For instance, Badejo (1995), and Adams (1998) established that the Niger River, after which the country is the named, and Benue, its largest tributary, are the main rivers whose channels provide the longest waterways into the hinterland of the country. Both rivers rise outside the country but meet at Lokoja confluence and later enter the gulf of Guinea through a large network of creeks and distributaries which form the Niger Delta. They also noted that rapids and falls are common along many Nigerian rivers and that these are partly responsible for the fact that navigation is not possible along certain parts of these rivers

In another study, Adams (1999) discovered that the capacity of Nigerian navigable waterways has increased to about 10,000 kilometers plus an extensive coastline of about 852 kilometers. Based on this, he noted that the country has a huge potential to move goods and passengers from the coast to the hinterland by water. Also Anyam (2003) regretted that the immense opportunities which the Nigerian inland waterways provide for business is yet to be tapped by potential investors. He established that despite her huge potentials, inland water transport is yet to become an alternative means of transportation to road and air such that passengers and cargo can sustainably and efficiently by moved to their destination through water. Similarly, Adams (2004) lamented that inland water transport is yet to receive the attention it deserves from the federal government particularly in the twin areas of funding and infrastructural development. He outlined the physical impediments to improved performance in the sector to include non channelization and dredging of navigable rivers, inadequate construction and rehabilitation of river ports, limited water transported infrastructures (comfortable boats, jetties and bouys) and safety and security concern along the navigable waterways

Ezenwaji (2010) focused on the poor use of inland rivers as transport routes in Nigeria. He compared the percentage share of that transport mode to others in Nigeria and elsewhere. He noted that in Bangladesh water transport constitutes 32\% of the transport sector (Rahmam, 1994); 20\% in Philippines (Fellinda, 2006); $3 \%$ in Sierra Leone (Kimba, 2008); $0.15 \%$ in India (Raphuram, 2004) and only $0.08 \%$ in Nigeria despite the country's rich endowment of inland waterways (that cover over 8.575 kilometers) and some innovative initiatives introduced by the Nigerian Inland Waterways Authority (NIWA). He established, like earlier researchers (Aderemo and Mogaji, (2010)), that several natural factors negatively affect the utilization of inland waterways as transport routes in Nigeria.

Akali and Idoko (2010), quoting Douglas, (2001) and Onuche, (2007) noted that inland water transportation plays a key role in the socio-economic and political development in Nigeria as a factor of exchange, mixing of population and sub-regional integration. They noted that this mode of transport facilitates the movement of bulky goods over long and short distances and that it is better appreciated when the source and destinations are water front locations. They concluded by observing that inspite of the tremendous advantages associated with inland water transport, there has been a considerable decline in its use in Nigeria.

In a recent study, Obed, (2013) established that the viable opportunities which inland water transport offer to investors include facility management, jetty operations and boat building. He agreed with an earlier observation that security concerns discourage potential investors form tapping into the viable business opportunities, which the Nigerian IWT provides. There have also been several reports of consultancies by development agencies and firms, aspects of which have dealt with diverse IWT development issues such as river channels dredging and maintenance, private sector involvement in the water transport sector, construction and rehabilitations of river ports, acquisition of passenger ferries, security boats, building of channels bouys and other projects. The conclusions reached are that investment apathy on the part of investors and conflicts between federal and state agencies involved in supervising IWT in Nigeria are some of the factors limiting the development of Nigerian's IWT

From the above review, it is crystal clear that the spatial structure of inland water transport operations, its major contributions, socio-cultural constraints-limiting its operations and policy trusts and targets etc remains 
largely unknown, hence the need for this study to bridge the existing gap in knowledge in the inland water transport sector in Nigeria

\subsection{METHODOLOGY}

This study involves among others, carrying out field investigations to determine the operational characteristics IWT in Nigeria and to describe the attitudes of locals towards this mode of transport in areas with already established inland waterways. Primary and secondary data were obtained and used in the study. Data on IWT infrastructure and attitudes of locals towards IWT were obtained through oral interviews, participant observations and from records in the Nigerian Inland Waterways Authority (NIWA) Lokoja; from the Federal Ministry of Transport headquarters Abuja and from water transport operators. Fifteen appropriate persons, comprising of water transport operators, passengers, government officials and boat users were interviewed at each of the sampled river port. Those interviewed were selected on the basis of availability, willingness to answer questions and long history of involvement in IWT operations. Twelve rivers ports from twelve states transverse by inland waterways were purposively selected and visited to conduct an on the spot assessment on the level of water transport operations, take photographs and interview operators of passengers ferries, jetties, boat builders, port workers, boat drivers and officials of state agencies that supervise inland water transport operations in Nigeria. Twelve states were chosen because they were those transverse by inland waterways. The twelve river ports purposively selected are shown in table 1

Table 1: Sampled Rivers Ports in Nigeria

\begin{tabular}{|c|c|c|c|c|}
\hline S/No & Sampled River $=$ ports & State & Latitudes & Longitudes \\
\hline 1 & Idah & Kogi state & $7^{0} 627.28^{\prime \prime} \mathrm{N}$ & $6^{0} 43^{\prime} 29.56^{\prime \prime} \mathrm{E}$ \\
\hline 2 & Baro & Niger & $8^{0} 36 ` 55.42^{\prime \prime} \mathrm{N}$ & $6^{0} 25^{\prime} 1.20^{\prime \prime} \mathrm{E}$ \\
\hline 3 & Oguta & Imo & $5^{0} 42 ` 26.55^{\prime} \mathrm{N}$ & $6^{0} 43^{\prime} 29.56^{\prime \prime} \mathrm{E}$ \\
\hline 4 & Degema & Cross River & $4^{0} 43^{\prime} 59^{\prime \prime} \mathrm{N}$ & $6^{0} 460^{\prime \prime E}$ \\
\hline 5 & Okirika & Rivers & $4^{0} 45{ }^{\prime} 0 “ \mathrm{~N}$ & $7^{0} 40^{\prime} \mathrm{E}$ \\
\hline 6 & Yenagoa & Bayelsa & $4^{0} 54 ` 56.52 ` \mathrm{~N}$ & $6^{0} 15 ` 55.90 ` \mathrm{E}$ \\
\hline 7 & Otuocha & Anambra & $6^{0} 20 ` 25.40^{\prime \prime} \mathrm{N}$ & $6^{0} 50^{\prime} 16.85^{\prime} \mathrm{E}$ \\
\hline 8 & Epe & Lagos & $6^{0} 34339.69 “ \mathrm{~N}$ & $3^{0} 58^{\prime} 39.26^{\prime \prime} \mathrm{E}$ \\
\hline 9 & Makurdi & Benue & $7^{0} 44^{\prime} 30.84^{\prime \prime} \mathrm{N}$ & $8^{0} 333^{\prime} 0.76^{\prime \prime} \mathrm{E}$ \\
\hline 10 & Burutu & Delta & $5^{0} 20 ` 59^{\prime \prime} \mathrm{N}$ & $5^{0} 300^{\prime}=\mathrm{E}$ \\
\hline 11 & Itu & Akwa Ibom & $5^{0} 12 \times 6.63^{\prime \prime} \mathrm{N}$ & $7^{0} 58^{`} 39.21^{\prime \prime} \mathrm{E}$ \\
\hline 12 & Sapele & Edo & $5^{0} 55^{\prime} 0^{\prime \prime} \mathrm{N}$ & $5^{0} 45^{\prime} 0^{\prime \prime} \mathrm{E}$ \\
\hline
\end{tabular}

Data collections on each river port were carried out by a trained research assistant who was also a native of the area where the port was sited. Locals who use their boats purely for non-commercial purposes (harvesting sand, fruits, firewood, going to farm, market, school etc.) were omitted from the interview. The entire field work was conducted between September $18^{\text {th }} 2011$ and April $14^{\text {th }}$ 2012. Secondary data used included information form books, journals, monographs, maps and form the internet. The data were analyzed using various simple statistical techniques such as totals, means, percentages, graphs etc.

\subsection{RESULTS AND DISCUSSION}

\section{Spatial Structure of Inland Water Transport in Nigeria}

Field investigations revealed that IWT is far more developed and consequently has a much more popular appeal among residents of the deltaic areas of southern Nigeria (Lagos, Rivers, Bayelsa, Akwa-Ibom and Cross River States) than in other parts of Nigeria. The variations in the level of patronage is shown in table

Table 2: Summary of the Spatial Structure of IWT in Nigeria.

\begin{tabular}{|c|c|c|c|c|c|c|c|c|}
\hline S/No & $\begin{array}{l}\text { Sampled } \\
\text { River } \\
\text { Ports }\end{array}$ & State & $\begin{array}{l}\text { Mean } \\
\text { weekly } \\
\text { volume of } \\
\text { passengers }\end{array}$ & $\begin{array}{l}\text { Percentage } \\
(\%)\end{array}$ & $\begin{array}{l}\text { No of } \\
\text { observed } \\
\text { commercial } \\
\text { vessel on the } \\
\text { busiest day } \\
\end{array}$ & $\begin{array}{l}\text { Mean }(\times) \\
\text { weekly No } \\
\text { of trips on } \\
\text { waterways }\end{array}$ & $\begin{array}{l}\text { No of observed } \\
\text { motorized } \\
\text { boats on the } \\
\text { busiest day }\end{array}$ & $\begin{array}{l}\text { No observed } \\
\text { canoes on } \\
\text { the busiest } \\
\text { day }\end{array}$ \\
\hline 1 & Idah & Kogi & 156 & 0.77 & 4 & 2 & 0 & 24 \\
\hline 2 & Baro & Niger & 152 & 0.75 & 6 & 3 & 0 & 11 \\
\hline 3 & Oguta & Imo & 194 & 0.96 & 8 & 3 & 1 & 9 \\
\hline 4 & Degema & Rivers & 1675 & 8.3 & 23 & 14 & 7 & 70 \\
\hline 5 & Okirika & Rivers & 2512 & 12.5 & 46 & 16 & 8 & 103 \\
\hline 6 & Yenagoa & Bayelsa & 3852 & 19.2 & 68 & 22 & 9 & 126 \\
\hline 7 & Epe & Lagos & 6230 & 30.9 & 148 & 14 & 14 & 77 \\
\hline 8 & Markurdi & Benue & 164 & 0.81 & 9 & 2 & 0 & 19 \\
\hline 9 & Itu & $\begin{array}{l}\text { Akwa } \\
\text { Ibom }\end{array}$ & 1865 & 9.3 & 21 & 2 & 5 & 46 \\
\hline 10 & Otuocha & Anambra & 170 & 0.84 & 8 & 8 & 0 & 22 \\
\hline 11 & Burutu & Delta & 1856 & 9.4 & 38 & 9 & 8 & 112 \\
\hline
\end{tabular}


The Characteristics Of Inland Water Transport In Nigeria

\begin{tabular}{|l|l|l|l|l|l|l|l|l|}
\hline 12 & Sapele & Edo & 1287 & 6.4 & 17 & 7 & 2 & 76 \\
\hline Total & & 20,143 & 100 & 366 & 102 & 54 & 695 \\
\hline
\end{tabular}

Source: Authors field work

Table 2 shows that passenger traffic is relatively higher in the deltaic states of Lagos (30.9\%), Bayelsa (19.2\%), Rivers (12.5\%), Delta (9.4\%), Akwa-Ibom (9.3\%), Cross River (8.3\%) and Edo (6.4\%) but low in other 5 hinterland states which collectively accounted for only $4.13 \%$ of the recorded passenger traffic within the weeks of study period. Also $92.8 \%$ of all the vessels used for commercial purposes are wooden canoes while only $7.2 \%$ are motorized boats. $98 \%$ of the motorized boats are used in the deltaic areas as commercial vessels owned and operated by commercial operators. Competition between water transport operators in this area was found to be stiff and the operators use various incentives to attract customers. A few comfortable and modern vessels are used in this zone and all operators pay taxes and levies to NIWA that supervise their operation. Respondents attributed the high patronage or popularity of IWT in the deltaic areas to the following factors:

1. The unique physical features of the area: The maze of creeks, rivers and lagoon is the area provide cheap and, for some communities, the only means of transportation. Also this mode of transport was found to be readily accessible, safe, flexible, meet local needs and is under the control and management of indigenous people. In addition, IWT allows the people to have access to other remote communities and for products and services to be distributed widely at lower costs.

2. Relative dense population: This provides adequate and a growing number of users of water transport facilities as well as market for primary and finished products which are transported between urban and rural areas

3. The impact of the oil economy: Oil companies particularly in Bayelsa, Delta and Rivers states have made the development of water transportation a priority. These companies are currently involved in dredging and widening river channels, provision of comfortable boats and jetties and in the installation of buoys and other water transport facilities. These facilities are used for the services of the staff of these companies and even passengers

4. The pattern of economic development in these states: Most of the agriculturally productive areas and oil wells in the region are located adjacent to navigable water channels

5. Government support/policies: The Bayelsa and Rivers state governments are presently investing in the development of water transport to help the people that live in the remote communities in the states.

In contrast the volume of human traffic along the waterways in other states (Edo, Imo, Anambra, Kogi, Niger, and Benue) (see table 1) was found to be typically lower than in Lagos, Bayelsa and Rivers and other deltaic states. The causes of the low volume of human traffic along the navigable rivers in these states were found to be complex but are generally related to socio-cultural influences (discussed in section 1.5) and easy access to road transport. Investigations revealed that inland water transport outside Lagos, Rivers Akwa-Ibom and Bayelsa states is characterized by:

I. Low volume of human traffic arising from low patronage

II. Use of uncomfortable vessels that exposes the passengers to environmental hazards-rain, wind, sun radiation etc.

III. Inadequate cargo assets as most traders and industrialists generally prefer to transport their goods by roads.

IV. Use of slow moving vessels

V. High levels of risks - the channels are not properly policed and robberies were reported to be frequent.

VI. Minimal competition between limited water and transport operators incentives to passengers

VII. Inadequate access to river ports by farmers who live in remote geographic locations.

VIII. Use of wooden canoes to transport the natural resources endowment of communities along the navigable channels, particularly forests products-timber, wood, leaves and herbs.

IX. Inadequate access to assistance by water transport operators to purchase and or maintain modern and comfortable boats or to recover from disasters such as floods, accidents robberies etc.

\subsection{The contributions of inland water transport to the Nigeria economy.}

Field investigations revealed that inland water transport, especially in the deltaic areas of Lagos, Rivers, Bayelsa and Akwa Ibom, plays a key role in rural development. Its use to move goods and services was found to fuel the economic growth and rural development of the local, coastal communities especially where it is the only means of transport available. An official of NIWA posited that IWT forms an integral part of the region social fabric and plays a pivotal role in assisting the people, especially the poor, in gaining access to social services, employment opportunities and in benefiting from the nations' economic agenda. IWT enhances rural productivity and it is necessary for the continued existence of the dispersed settlements in the region.

There were indeed reported and widespread evidences especially in the coastal states that IWT promotes all facets of agro and other businesses- ranging from crop production through fishery, production of basic materials, processing of timber products to the promotion of rural development etc. Findings revealed that 
this mode of transport promotes the growth of rural economics, both through its direct positive impacts on commerce, agriculture and industries. In addition, it offers hundreds of millions of people the opportunity to produce or purchase sufficient food, fish and other goods, especially in the remote coastal communities where it remains the only means of transport available. The respondents identified additional benefits which included employment and income generation, NIWA officials estimated that over 125,000 persons are directly employed by the IWT in each of the deltaic states in Nigeria and that tugboat operators earn about $\$ 4,000$ daily. Also identified were income generation, reduction of haulage costs and opening up the settlement and economic frontiers of remote and inaccessible areas. As a respondent in Akwa Ibom state posited, this mode of transport allows products and services to reach them in their remote villages and also allow people to benefits from the dividends of democracy. This is an essential component of the rural development agenda of the present federal government of Nigeria. IWT according to the Alwa-Ibom state respondent it also enables the locals to move away from geographical areas and sectors that are most affected by oil spillage which occur frequently in the Niger Delta

\subsection{Socio-Cultural Factors Impending IWT outside the Deltaic Areas}

Earlier workers (Ojile, 2006; Ezenwaji, 2010) have established the natural factors which impede performance of IWT in Nigeria. In this research we extended this by focusing on the socio-cultural attitudes that constrain the growth of IWT in Nigeria because the emphasis on physical constraints makes sense but gives an incomplete picture. Several socio-cultural factors were identified and described; the leading one, however, is the low preference or dislike for IWT by many potential users, especially outside the deltaic areas. Many potential users outside the Niger Delta region revealed a general dislike or low preference for IWT, In Idah urban area, for instance, the plastic, cosmetic and provision dealers, who constitute obvious potential users, since they sourced their goods from Onitsha, and sale same in Idah and Aganibode, on either side of the Niger, displayed a clear dislike for travelling along waterways. $82 \%$ of those interviewed have never transported their goods across the River Niger waterway. Their dislike for this mode of transport is not just related to the nature of the vessels used (ie. whether comfortable or not, slow or fast). Inland water transport according to these respondents is full of risks (accidents, robberies, attack by reptiles etc.) and is, in addition, best suited for people who can swim or are armed, or escorted by security personnel.

Secondly, there was also this superstitious belief among some locals of the communities bordering the navigable rivers about the existence of a mythical water spirit that takes a human life, in alternate yeasts, from those who sail on the streams. Thirdly, majority of the respondent's belief that government is not genuinely interested in funding and developing IWT probably because majority of the users are the poor and marginalized. Successive government policies and programmes, on transport development have, according to them, concentrated largely on roads and air to the detriment of water transportation. Apart from government neglect, corruption was also said to be impacting negatively on IWT sector in Nigeria. It hampers efforts in solving the problems of inadequate water transport facilities and partly accounts for the why IWT facilities are under developed and of poor quality.

\subsection{Other Features of IWT in Nigeria}

$i$. $\quad$ Current Navigable Inland Waterways in Nigeria

The current wet and dry season navigable rivers and creeks in Nigeria are shown in fig. 1. As fig. 1 shows, the creeks and the Niger, Benue, Cross River Ogun and Anambra Rivers are the main navigable rivers in Nigeria currently. Findings also revealed that the total navigable section has risen from less than 8,000 Kilometers in 1970 to over 10,800 kilometers presently. This increase resulted largely from the dredging o the lower Niger River and from the channelization of Ogun, Anambra and Benue Rivers. For instance, the Niger River was navigable only up to Jebba in the 1980s but now the improvements at Kainji have made it possible (especially for lighter vessels) to navigate right through to the frontier. 


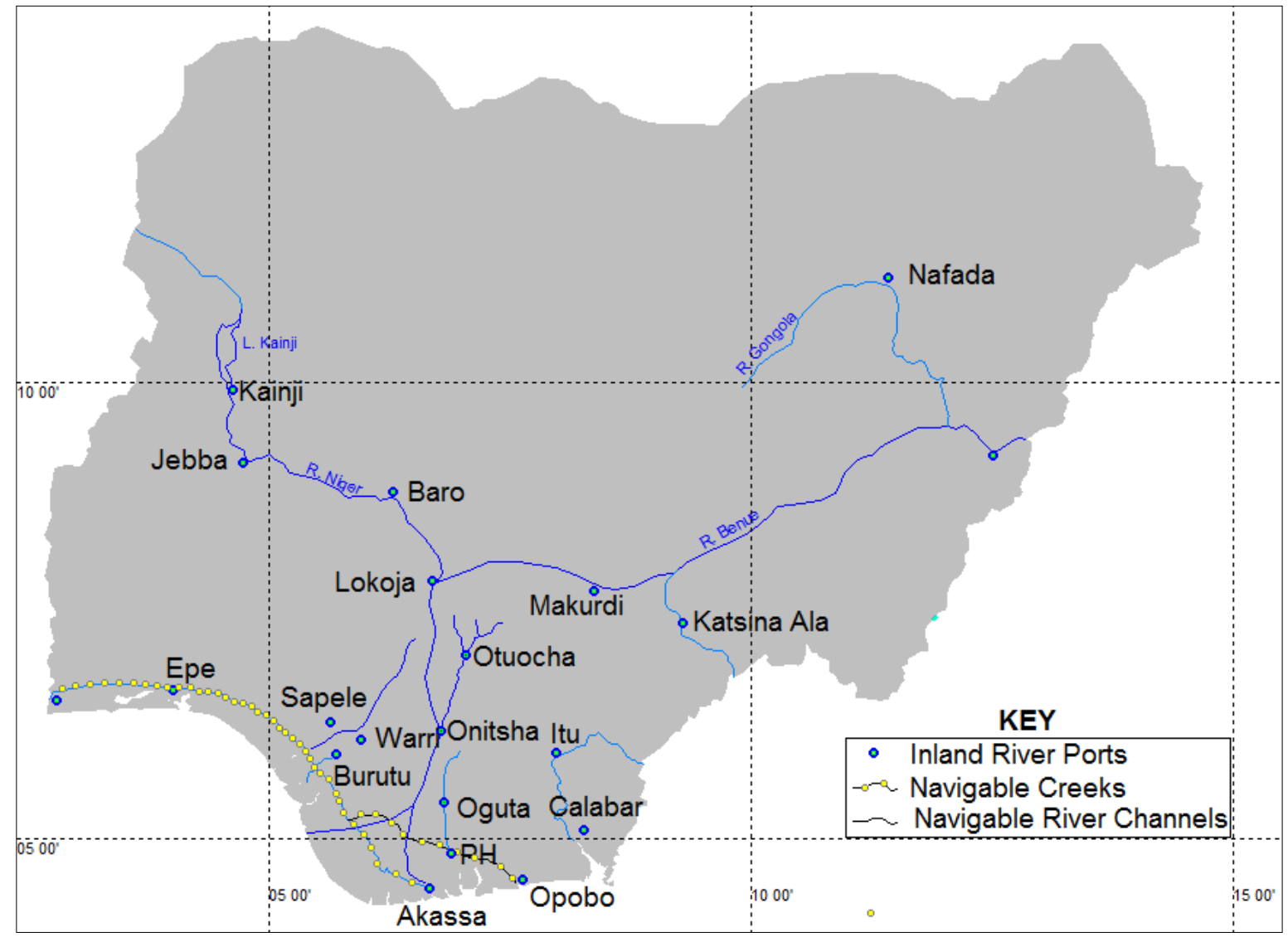

Source: Nigerian Inland Waterway Authority (NIWA), 2012

Fig. 1 Inland River Ports in Nigeria

\section{ii. $\quad$ Goods transported by inland water operators in Nigeria}

Investigations revealed that the nature of the goods transported by IWT operators in Nigeria is largely influenced by the aspects of the settlement pattern and agricultural practices along the navigable channels of the rivers. Plant resources tools and manufactured items were found to be the main cargo transported along these river channels. A journey from Baro, through Lokoja, Idah, Onitsha to Warri, along the Niger will reveal rich agricultural zones, vast forest areas and settlements which generate much of the cargo transported along the river channels. Table 3 shows the observed type of the goods carried along the inland water transport system through the use of canoes and boats.

Table 3: Goods Transported Along the Nigerian Inland Waterways

\begin{tabular}{|l|l|l|l|}
\hline S/No & Category of Goods & Examples & Direction of Movement \\
\hline 1 & Agricultural products & Yam, maize, vegetables etc. & Either form farms or to the markets \\
\hline 2 & Plant Resources & $\begin{array}{l}\text { Firewood, leaves, roots, fruits, } \\
\text { timber etc. }\end{array}$ & $\begin{array}{l}\text { Either from forests/bushes or to the } \\
\text { markets. }\end{array}$ \\
\hline 3 & Manufactured goods & $\begin{array}{l}\text { Plastics, drinks, books clothes, } \\
\text { cement, iron etc. }\end{array}$ & $\begin{array}{l}\text { Either from markets to markets or from } \\
\text { markets to home }\end{array}$ \\
\hline 4 & Cultural items & $\begin{array}{l}\text { Musical and religious implements } \\
\text { etc }\end{array}$ & Same as above \\
\hline 5 & Harvest fish & $\begin{array}{l}\text { Fishes caught along the rivers by } \\
\text { fishermen }\end{array}$ & $\begin{array}{l}\text { Either from river to home or from home } \\
\text { to markets }\end{array}$ \\
\hline 7 & Raw materials & Palm oil, kernel, water etc. & Either to factories or to markets \\
\hline 8 & Tools & $\begin{array}{l}\text { Farming tools and tools for building } \\
\text { canoes etc. }\end{array}$ & Either to homes, farms, forests or markets \\
\hline 9 & Building materials & Fuel, kerosene etc. & Either to or from the markets \\
\hline 10 & Machinery and equipment & Wand, gravel, stores & $\begin{array}{l}\text { Either to homes or factories } \\
\text { industries, markets etc. }\end{array}$ \\
\hline
\end{tabular}

Source: Author's field work 2012 


\subsection{CONCLUSION AND RECOMMENDATIONS}

Provision of efficient IWT system for local residents within and outside the deltaic communities is one of the major challenges facing successive governments in Nigeria. Residents of many remote, riverrine communities lack regular access to reliable, all-season road networks. Motorized transportation services, where available are inadequate, inefficient and very costly, especially for the poor and marginalized. As a result the people suffer continually from the problems of inadequate IWT facilities and services. The result is that the high agricultural potentials, abundant natural resources and other rural enterprise remain cut off due to inadequate and unreliable transport facilities and services. To radically reposition IWT in Nigeria, its facilities and services have to be efficient, affordable, appropriate and dependable. Water transport operators must priotise safety, quality, speed and flexibility. The federal government and the private sector must adopt innovative and positive actions and give full support to policies put in place to accelerate the development of IWT in Nigeria. Specifically, the recommendation suggested below may assist in this regard

\section{Creation of enabling environment}

The federal government should promote private sector participation in the industry by improving the investment climate, expanding and developing the country's water infrastructure, widening and deepening more river channels and building new roads to link agricultural and mining areas to the river ports. Government also needs to create an enabling environment for private sector participation. This could be achieved through the development of innovative action plans as well as policy consistency that could deliver profitable IWT operations in the country.

\section{Private sector participation}

The private sector, on the other, should co-operate maximally with the government agencies that supervise IWT and in addition purchase new jetties, comfortable and fast boats, and contribute in the development of the country's water infrastructure either in partnership with the government or independently Attainment of sustainable and profitable IWT operations in Nigeria requires these practical, innovative and collaborative efforts by all the stakeholders'- especially by the private sector.

\section{Research}

The creation of new knowledge and expertise through research and the provision of improved facilities will enhance IWT operations in Nigeria.

\section{Review of operational strategies}

To overcome the current problems facing the sector and to lay the foundation for accelerated progress in the future, government and the private sector need to thoroughly review their policies and investment strategies. In doing this, they must take into account many factors, including how to evenly spread water transport facilities, reduce robbery and criminality along the waterways, review taxes and levies paid by water transport operators and introduce new strategies which can make water transport compete favourably with road transport in Nigeria.

\section{Creation of awareness}

There is need to create awareness among the potential IWT users in Nigeria on the inherent benefits and desirability of transporting their cargo through inland waterways. This could be achieved through the use of the local media, workshops and town hall meetings. The people should be made to realize that the talk of a water spirit that kills sailors along the river channels is nothing but superstition and that superstitions have no scientific basis. Workshops will provide the users with unique opportunities to discuss the challenges confronting IWT such as security and safety concerns, cultural and attitudinal patterns, multiple taxation and levies imposed on the operators, high operating cost and reliance on outdated transport Acts and policies.

\section{Modernize the river ports}

The federal government should further strengthen IWT by deepening and modernizing the inland river ports so that they can be put into fruitful economic uses.

\section{References}

[1]. ABAMS, T.K.S (1998): Niger Delta Environmental Survey (1998): Phase Two Report on Hydrology and Hydrodynamics.

[2]. ABAMS, T.K.S (1999): "Dynamic and Quality of Water Resources in Niger Delta" In Bryan Ellis (ed). Impacts of Urban Growth on Surface Water and Groundwater Quality.

[3]. ABAMS, T.K.S (2004): Geohydrology with Application to Environmental Management. Charisma Graphic Pub, Port-Harcourt, pp.126-127.

[4]. ABUBAKAR, M.A(2002): Dialogue on Power Potential and Prospects of the Inland Waterways in Nigeria. Adams printing press, Kano, Nigeria. 
[5]. ABUBAKAR, A.I (2012: Desk Officer, Water Transportation Unit, Federal Ministry of transport, Abuja, Nigeria. Personnel communication.

[6]. ADEREMO, A.J.\& MOGAJI, S.A (2010): "Rural Transportation of public Facilities in Nigeria: a case study of Edu Local Government Area of Kwara State" Journal of Human Ecology, Vol. 29 no. 3, pp 171-179.

[7]. ADETOLA, J.B.C (1971): "Geography" Notes and Modern Answers, Omolayo Standard Publishers, Ibandan, Nigeria

[8]. AGAGWU, R. (2009): "We Need to Focus Efforts on Water Transport" in Adabu, J.J. (ed) Inland Waterways and Coastal Transportation in Nigeria. Cass Press, Enugu

[9]. AKALI, K.E, AND IDOKO, O. (2010): River Transport and Economic Empowerment; An Assessment of Lokoja Crossing Port on the Niger Being a Paper Delivered at the $53^{\text {rd }}$ annual Conference of Association of Nigerian Geographers (ANG) at lagos state university, Lagos Between Nov. $21^{\text {st }}-$ Nov. $25^{\text {th }} 2011$.

[10]. AMINU, A. (2010): "The Socio-Economic Implications of the Dredging of River Niger". Drainage basin Studies, Vol. 8 , No. 2 pp $115-121$.

[11]. ANGAYE, S.M.S (1990): "The Climate, Vegetation and Forest of the Niger delta". Journal of Geographic Thought 1 (1): $20-25$

[12]. ANYAM, R.W. (2003). "The Complexity and dynamics of man-environment interactions in Nigeria". Paper presented at the First stakeholders' workshop on Environmental Policy for Benue State Held on the $15^{\text {th }}$ October 2003 Benue state university, Makurdi.

[13]. AYOADE J.O (2004): Climate Change. Ibadan. Vantage Publishers Pp 45-66.

[14]. DOUGLAS, I.E. (2001): "Impact of Navigation on Socio-economic Development of West and Central Africa sub-region and as a veritable tool for the promotion of tourism and sports". A paper presented at a 3-day International Conference on Navigation activities within the Niger River Basin West and Central Africa Sub-region, held at Abuja on the $26^{\text {th }}-28^{\text {th }}$ June, $^{2001}$.

[15]. EZENWAJI, E.E. (2010): Constraints on Effective Water Transportation in some Riverine Communities of Old Anambra L.G.A., Anambra State". A Paper delivered at the 2010 Rural Development Seminar with the theme Rural Transportation in Nigeria. Imo State University, Owerri, $31^{\text {st }}$ March to $1^{\text {st }}$ April, 2010.

[16]. FELLINDA, L. (2006): "World's Water Transport needs further Development". Transport and Development, pp 68-72.

[17]. GRAY, L. (2004): "An examination of the problems of water transportations in old Degama Province, Nigeria". Journal of Waterways, Africa, No. 33, pp 20-26.

[18]. ILOJIE I.J. (1984): Regional Geography of Nigeria Macmillan Pub. Lagos, Nigeria

[19]. KIMBA, G. (2008): "Development of inland waterways in Freetown Sierra Leone". Journal of African Integration, Vol. 3, pp 91 100.

[20]. LAWANSON, T. O. (2006): Challenges of sustainability and urban development in Nigeria: Reviewing the Millennium development Goals

[21]. NDIKOM B.C (2008): Maritime Transport Management and Administration in Nigeria. A paper Presented at TASEE: Ijebu-Ode, Ogun State.

[22]. NYABANGO, R. N. (2010): “Transportation in the East African Lake Region”, Journal of African Development, Vol. 3, No. 1, pp 114-119.

[23]. NYELONG P. N. (2004) "Global warming and global waters" Journal of Energy and Environment 17(1) pp. 79-90

[24]. OBED, B.C.N (2013): "A Critical Assessment of the Inland Waterways Operations and Management of the Development of Nigerian Maritime Industry" Greener jounal of environmental management and public safety Vol. 2, No 2 Pp 99-17

[25]. OJILE, MESHACH OWHO (2006): Draft Report of the Socio-Economic Characteristics for the Idealization of the Port Harcourt Warri Roads Submitted to Messer allots Nigeria. Limited on behalf of the Federal Ministry of Works, Abuja. P60

[26]. OJILE, MESHACH OWHOTEMU (2007): "Economic Development, Urban Growth and Impacts: Issues of Livelihood, Vulnerability and Sustainability in Yenagog Metropolitan Area, Bayelsa State, Nigeria: A paper Presented at the $22^{\text {nd }}$ IAIA Conference, INNA07 3-9 June, Seoul, Korea. Pp 27

[27]. OKIO, B.B. (2006): “On the Advantages of water transportation”, in Negros, J.N. (ed.) Water and African Development, Minita Press, Addis Ababa.

[28]. ONUCHE, H. A. (2007); Assessment of Inland water transport at the Lokoja Crossing Port. An M.Sc thesis submitted to the Department of Geography, Benue State University, Makurdi.

[29]. RAHMAN, M. (1994): "National Transport System in Bangladesh". Asian Transport Journal, vol. 21, pp 18-23.

[30]. RANGARA, N, \& RAGHURAM, G. (2007): "Viability of Inland Water Transport in India". ADB/IMRM Policy Brief, No. 13, pp 3-7.

[31]. RAPHURAM, G. (2004): "Integrating Coastal Shipping with National Transport Network in India". Proceedings of the International Association of Maritime Economics Annual Conference. Vol. 11, No. 1, pp 39-48.

[32]. UDO, R.K (1970): Geographical Regions of Nigeria. OUP, Ibadan Nigeria 